\title{
LANDSLIDE RISK MAPPING ALONG RANTEPAO - PALOPO ROAD SECTION, SOUTH SULAWESI PROVINCE
}

\author{
Dian Pratiwi Anggeraini \\ National Road Implementation Office VI, Ministry of Public Works, Makassar, Indonesia \\ dianggeraini@gmail.com
}

\begin{abstract}
Rantepao - Palopo Road Section is $61 \mathrm{~km}$ long, which provides a connection between Palopo City and North Toraja District. Geographically, the road is winding, located in a hilly area with steep canyon. This condition makes the road vulnerable to soil movement or landslide. On 8 November 2009, a landslide, which caused a huge material and immaterial loss, took place. The scale of the disaster was so large that it was classified as a national disaster. In the landslide disaster management, the mitigation and preparedness effort will be more focused if complemented with spatial data in the form of landslide hazard map in Rantepao - Palopo road section. This research uses Public Works Minister Regulation No.22/PRT/M/2007 concerning landslide hazard area spatial planning as the reference which is modified and assisted with the application of Geographical Information System (GIS). Based on the topographical condition, the research location can be classified into three, namely typology A (> $1000 \mathrm{~m} \mathrm{msl})$, typology B $(500-1000 \mathrm{~m} \mathrm{msl})$, and typology C $(<500 \mathrm{~m} \mathrm{msl})$. Each typology consists of natural physical aspects with slope indicator, soil type, geology, rainfall, distance from the river/slope water system, distance from seismic fault and vegetation. Human activity aspects comprise planting pattern indicator, slope cutting, pond, population density, and mitigation effort. Based on the regulation, several indicators are difficult to apply in the road section study. Therefore, in this research, some modifications are made to several indicators. In the slope cutting indicator, to obtain slope cutting map, overlay process on topography map, slope variation map, and road section map was performed. The distance from the river/slope water system was obtained by calculating the distance from the river to the road, the closer the river to the road, the bigger the vulnerability. Meanwhile, the distance from the fault was evaluated based on the existence of seismic faults in the research location. Landslide hazard map was obtained by applying overlay process to natural physical aspects map and human activity map. To obtain a hazard map for Rantepao - Palopo road section, a modification by applying overlay to road section map and landslide hazard map was performed. Risk map on Ranteo-Palopo is divided into three types, i.e. low risk, medium risk, and high risk.
\end{abstract}

Keywords: landslide, hazard risk map, Rantepao - Palopo road, disaster mitigation

\section{INTRODUCTION}

Palopo City is a city in South Sulawesi Province which lies between latitudes $2^{\circ} 53^{\prime} 15^{\prime \prime} \mathrm{S}-3^{\circ} 04^{\prime} 08^{\prime \prime} \mathrm{S}$ and longitudes $120^{\circ} 03^{\prime} 10^{\prime \prime} \mathrm{E}-120^{\circ} 14^{\prime} 34^{\prime \prime} \mathrm{E}$. It has an area of $247.52 \mathrm{~km}^{2}$. Palopo City is divided into 9 sub-districts which are connected to North Toraja District (Rantepao) via the $61 \mathrm{~km}$ long Rantepao Palopo road section. The road section is winding, located in a hilly area with steep canyon, all of which causes the road to be vulnerable to soil movement or landslide.

Based on Directorate General of Bina Marga (2009), the landslide taking place on 8 November 2009 in Rantepao - Palopo road section had 40 landslide spots with damage scale from medium to high and 80 landslide spots with low damage scale. To anticipate a more severe damage, a countermeasure / mitigation effort to anticipate disaster risk is vastly necessary. One of the efforts is by conducting disaster risk management through an evaluation of landslide potential/risk, which result is then used to formulate landslide hazard map in Rantepao - Palopo road section.

The research is aimed at conducting mapping on landslide hazard along the Rantepao - Palopo road section, particularly in West Bara sub-district as the research location to minimize the risk from the landslide. The purposes of this research are to give description on the condition of the controlling factor and triggering factor of landslide disaster in Rantepao - Palopo road section, to conduct the landslide hazard mapping in Rantepao - Palopo road section, to give recommendation as disaster mitigation efforts in Rantepao - Palopo road section.

\section{LANDSLIDE DISASATER MANAGEMENT}

Public Works Minister Regulation No.22/PRT/M/2007 defines landslide as soil/rock mass movement process that slides from the original position so that it is separated from solid mass due to gravity while Karnawati (2005) defined landslide as soil, rock mass movement or slope composing material namely combination of soil and rock which moves downward due to gravity force. The trigger of 
landslide or soil movement is the loss of soil stability in a slope or certain location due to several factors, through natural process, unnatural process, or the combination of both processes. Karnawati (2005) explained that landslide occurs due to the existence of movement controlling factors, among others geomorphology, soil, geology, geohydrology, and land use, and movement triggering process such as water infiltration to the slope, seismic activity, human activity or land use change.

Public Works Minister Regulation No.22/PRT/M/2007 (Ministry of Public Works, 2007) on landslide prone area spatial planning classifies disaster prone area into two aspects that are susceptibility level based on natural physical aspects and vulnerability level based on human activity aspects. Susceptibility indicators based on natural physical aspects include slope, soil type, slope composing material, rainfall, slope water system, seismic, and vegetation whereas vulnerability indicators based on human activity are among others planting pattern, slope cutting and slope excavation, pond, drainage, constructions, population density, and mitigation efforts. Landslide prone area is an area which is vulnerable to landslide due to the geologic sensitivity to disturbance, natural or human made as soil movement triggering factor.

Based on Law No. 24 Year 2007 on Disaster Management, mitigation is a series of efforts to reduce disaster risk through physical construction and improvement of community capacity in anticipating disaster risk. Disaster mitigation is a cycle of disaster management divided into 4 steps, namely, efforts taken long before disaster occurs, preparedness when disaster is about to occur, post disaster emergency response, and rehabilitation effort.

Geographic Information System (GIS) is an information system which is designed to work with data referenced by spatial or geographic coordinates. In other words, GIS is data base system with special capabilities for handling spatial referenced data working in conjunction with a set of operations (Barus \& Wiradisastra, 2000).

\section{RESEARCH METHODOLOGY}

\subsection{Research Location}

The research scope of work is Rantepao - Polopo road section which is included in the administrative area of Palopo City, an autonomous city in South Sulawesi Province with an area of $247.52 \mathrm{~km}^{2}$. However, spatial analysis and study uses regional data focusing on West Wara sub-district area.

\subsection{Data Collection}

Data collection needed for this research is primary and secondary data. The primary data is data from direct observation in the landslide area. The secondary data is rainfall data, topographic map, geology map, land use map, and road network map.

\subsection{Field Survey}

Field survey is an activity where the primary data is collected directly in the research location through direct observation in the research location or interview with local community. The data obtained from this activity is inventory data at every landslide spot, comprising landslide spot identification, landslide type characteristic, landslide causing factors, and identification of efforts that have been conducted as landslide mitigation efforts in the road section in the research location.

\subsection{Map Digitizing and Indicator Analysis Phase}

Data analyzing process through digitization of every landslide vulnerability indicator with reference to Public Works Minister Regulation No.22/PRT/M/2007 (Ministry of Public Works, 2007) on landslide prone area spatial planning, classifies disaster prone area into two aspects that are susceptibility level based on natural physical aspects and vulnerability level based on human activity aspects based on the typology of the landslide prone area.

The susceptibility, vulnerability, and risk analysis used GIS (using ArcGis 9.3) with analysis phases as follows (Danoedoro, 2004; 2008):

a) Digitalization of landslide prone area typology.

b) Digitization of susceptibility map based on natural physical aspects, comprising slope variation, soil condition, slope composing rock, distance from river/slope water system, distance from seismic fault and vegetation.

c) Digitization of vulnerability map based on human activity aspects, comprising planting pattern, slope cutting and excavation, pond, population density, and mitigation effort.

d) Weighting and scoring process. Weighting and scoring process of landslide vulnerability level based on natural physical aspects, human activity aspects referring to Public Works Minister Regulation No.22/PRT/M/2007 (Ministry of Public Works, 2007) which is modified from the 
result of previous research. In the scoring process, a study using trial and error method to obtain indicator weight appropriate for the research location was performed.

e) Overlay process was performed to obtain new theme map in the form of soil movement susceptibility map based on natural physical aspects, and human activity aspects. Landslide hazard map as the result of overlay on susceptibility map based on natural physical aspects and vulnerability map based on human activity aspects. Rantepao - Palopo road section risk map which is the result of overlay between landslide hazard map and road section map.

\section{RESULTS AND DISCUSSIONS}

\subsection{Typology of Landslide Prone Area}

The typology of landslide prone area in the research location is classified into several zones through hydrogeomorphology approach in accordance to Public Works Minister Regulation No.22/PRT/M/2007 (Ministry of Public Works, 2007) on landslide prone area spatial planning. The landslide prone area in the research location is categorized into three zone types, i.e. A typology including landslide prone area in mountain slope area, mountain slope, hill slope, hilly slope, and riverbank with elevation of > $1000 \mathrm{~m}$ msl., B Typology including landslide prone area in the foot of the mountain, the foot of mountainous area, the foot of hill, the foot of hilly area, and riverbank with elevation of 500-1000 m msl., C typology namely landslide prone area in plateau, low land, level land, riverbank or river valley with elevation $<500 \mathrm{~m} \mathrm{msl}$.

\subsection{Susceptibility Based on Natural Physical Aspects}

The susceptibility indicators based on natural physical aspects constitute of 7 indicators (Ministry of Agriculture, 1980) which weights are $30 \%$ for slope variation, $15 \%$ for soil type, $20 \%$ for slope composing material, $10 \%$ for rainfall, $7 \%$ for the distance from the river /slope water system, 5\% for the distance from seismic fault and $13 \%$ for vegetation. The scoring on the weight of each indicator based on natural physical aspects is conducted by multiplying indicator weight with scoring weight that can be seen in Figure 1.

\subsection{Vulnerability based on Human Activity Aspects}

The vulnerability indicators based on human activity aspects comprise 5 indicators (Ministry of Agriculture, 1980), i.e. $16 \%$ for planting pattern, $22 \%$ for slope cutting, $16 \%$ for pond, $30 \%$ for population density, and $16 \%$ for mitigation effort. The scoring on the weight of each indicator based on human activity aspects is conducted by multiplying the indicator weight with scoring weight as seen in Figure 2.

\subsection{Landslide Hazard Map and Hazard Map of Rantepao - Palopo Road Section}

The landslide hazard map at Rantepao - Palopo road section is a combination of landslide susceptibility map based on natural physical aspects and landslide vulnerability map based on human activity aspects which was obtained through spatial analysis by multiplying indicator weight with scoring weight as seen in Figure 3. Rantepao - Palopo Risk Map is a combination of landslide hazard map and Rantepao Palopo road section map, through spatial analysis using ArcGis 9.3 program as seen in Figure 4. 


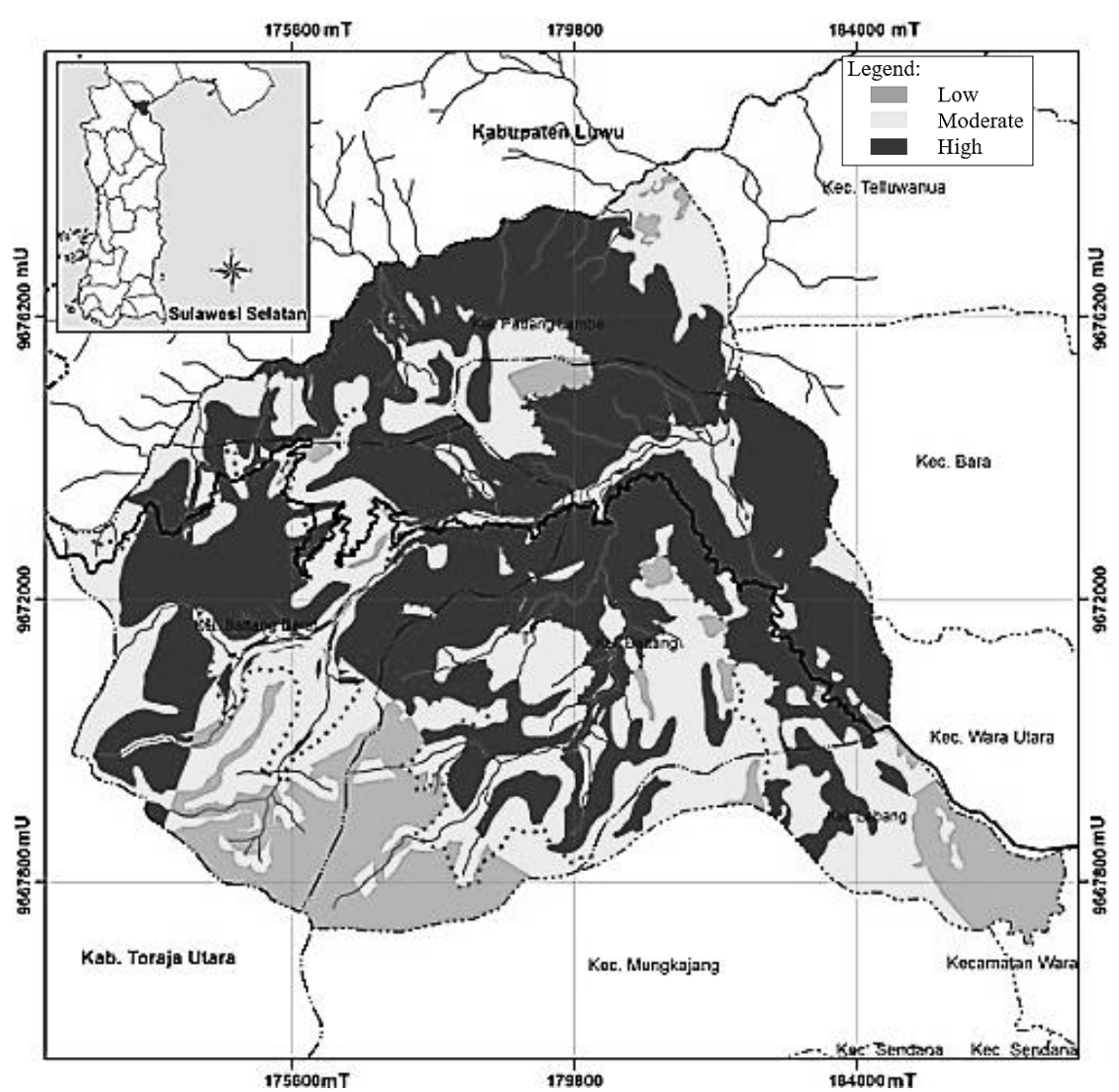

Figure 1. Landslide susceptibility map based on natural physical aspects (Ministry of Public Works, 2007).

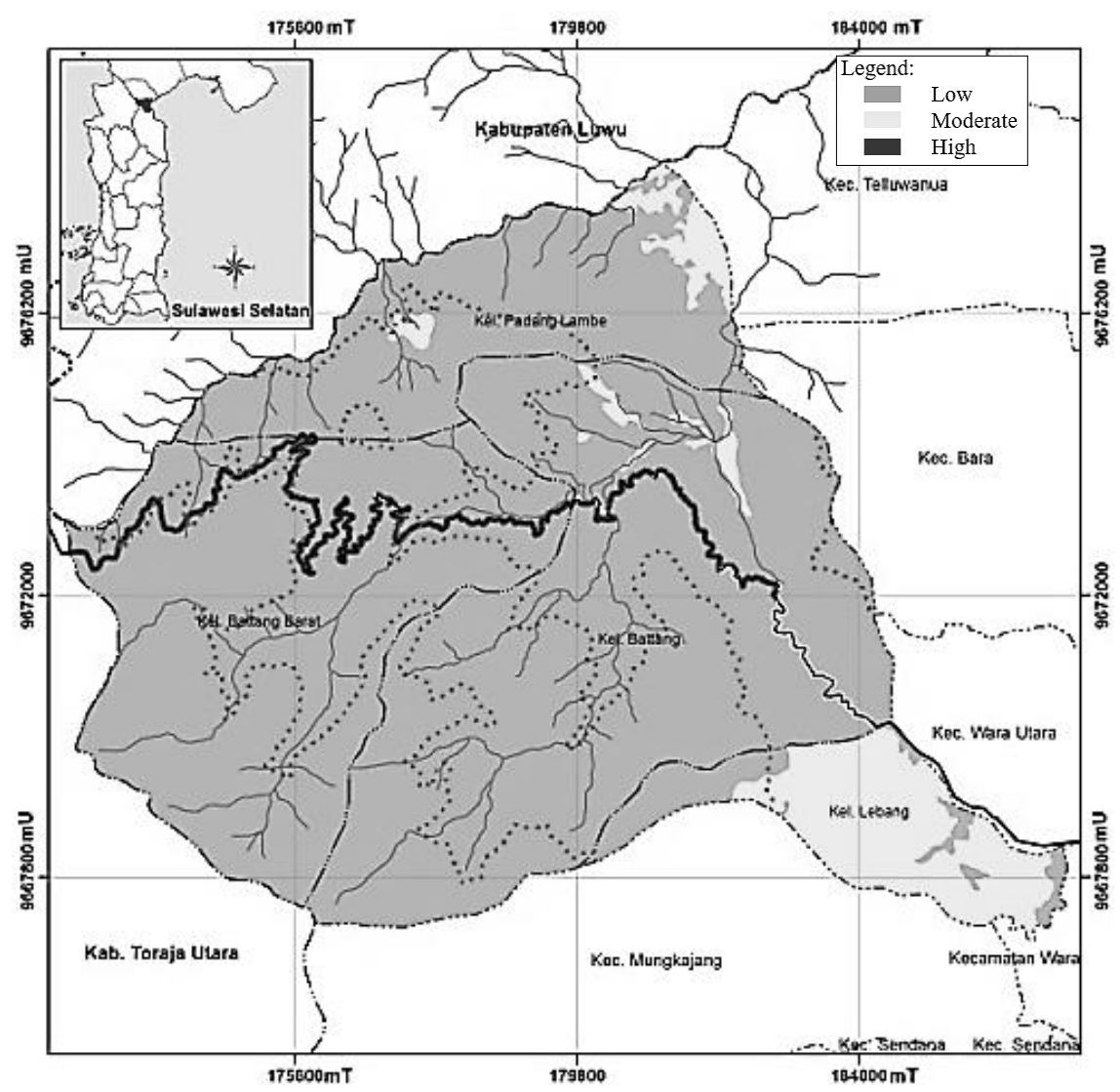

Figure 2. Landslide vulnerability map based on human activity aspects (Ministry of Public Works, 2007). 


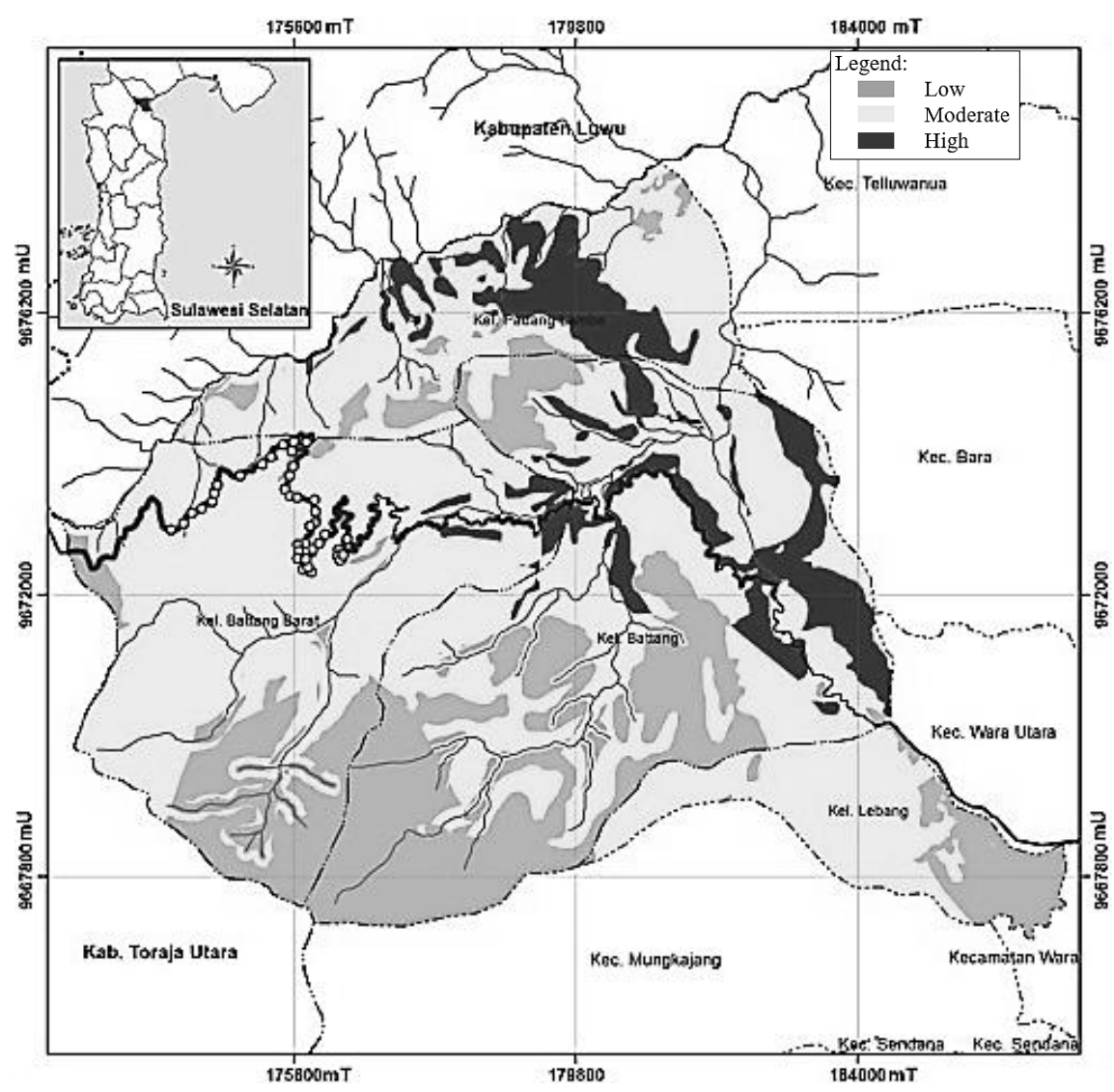

Figure 3. Landslide hazard map in West Wara Sub district, Palopo City.

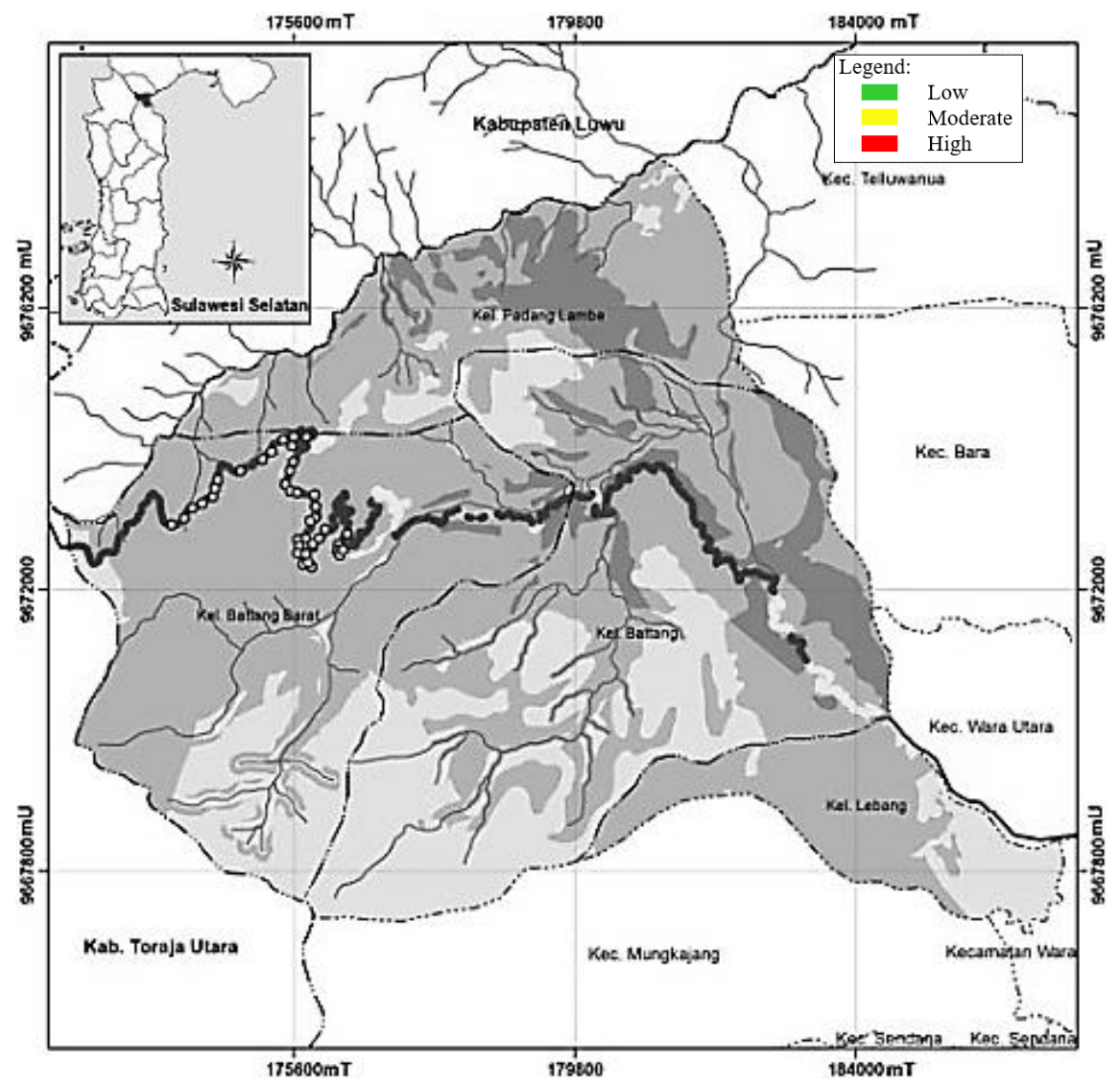

Figure 4. Rantepao - Palopo Road Section Map in West Wara sub-district, Palopo City. 


\section{CONCLUSIONS AND RECOMMENDATIONS}

\subsection{Conclusions}

According to the research results, some conclusions that can be summarized are as follows:

a) Based on the geomorphology condition, the research location is classified into three typology, which are A type zone (2,347.42 ha), B type zone (3,624.73 ha), and type $\mathrm{C}$ zone $(3,890.77 \mathrm{ha})$.

b) The analysis of landslide susceptibility map based on the natural physical aspects shows that the susceptibility in A type zone which is divided into high potential (749.65ha), medium potential (750.98ha), and low potential (846.80ha). B type zone is divided into high potential (1,513.66ha), medium potential $(1,930.92 \mathrm{ha})$, and low potential (180.15ha). C type zone is divided into high potential (2,635.43ha), medium potential (931.75ha), and low potential (323.59ha).

c) The analysis of landslide vulnerability map based on the human activities aspects shows that the vulnerability in A type zone is classified into high potential (29.25ha) and low potential (2,318.17ha). B type zone is classified into high potential (113.86ha), medium potential (46.91ha), and low potential $(3,463.96 \mathrm{ha})$. C type zone is classified into high potential (89.11 ha), medium potential (902.94ha), and low potential (2,898.71ha).

d) The analysis of landslide hazard map shows that the landslide risk potential in A type zone is divided into high potential (29.24ha), medium potential (1,110.98ha), and low potential $(1,207.20 \mathrm{ha})$. B type zone can be divided into high potential (109.68ha), medium potential $(2,475.11 \mathrm{ha})$, and low potential (1,039.94ha). C type zone is divided into high potential $(1,034.18 \mathrm{ha})$, medium potential $(2,561.42 \mathrm{ha})$, and low potential (295.17ha).

e) The result of landslide hazard study on the road shows that the road section with high risk is $22.53 \mathrm{~km} / 76.36 \%$, medium risk is $6.69 \mathrm{~km} / 22.71 \%$, and low risk is $0.27 \mathrm{~km} / 0.92 \%$.

f) The result of map analysis shows that the controlling and triggering factors of landslide in Rantepao - Palopo road section are the slope condition, the soil type which is sandy and instable, high rainfall, the existence of river and seismic fault which are close to the road section, and prone to collapse. Other than natural factors, human activities, namely slope cutting, also caused the landslide.

g) Several recommendations on landslide mitigation efforts are slope stabilization by reducing/flattening slope angle, filling/sealing slope cracks, planting vegetation which enhances slope stability. Strengthening the supporting structure of slope stability can be conducted by constructing shot Crete, gabion wall, stonewall and retaining wall. Beside structural mitigation effort, non-structural mitigation efforts such as provision of buffer zone, road sign installation, resettlement, and the formulation of supporting regulation to manage the surrounding environment in the landslide prone area should be conducted.

\subsection{Recommendations}

Some recommendations considered important for the next research are as follows:

a) The result of this research is non-technical; therefore, if a technical management will be conducted, a further research is necessary.

b) An analysis on the slope stability in the road design at the research location is needed.

c) Formulation of regional regulations and policies in landslide prone area spatial planning and management is needed and should be followed by real action by the community and related government institutions.

\section{REFERENCES}

Barus, B. \& Wiradisastra, U., 2000. Sistem Informasi Geografi, Laboratorium Penginderaan Jauh dan Kartografi, Bogor: Faculty of Agriculture, Bogor Agriculture Institute.

Danoedoro, P., 2004. Pengolahan citra Digital, Teori dan Aplikasinya Dalam Bidang Penginderaan Jauh [Digital Processing Image, Theory, and Application in Remote Sensing], Yogyakarta: Faculty of Geography.

Danoedoro, P., 2008. Matrikulasi GIS dan Remote Sensing [Matriculation of GIS and remote Sensing], Yogyakarta: MTPBA Universitas Gadjah Mada.

Directorate General of Bina Marga, 2009. Laporan Longsoran Jalan Nasional Rantepao - Palopo, Provinsi Sulawesi Selatan [Lanslide Hazard Report on National Road Rantepao - Palopo, South Sulawesi Province]. Directorate General of Bina Marga.

Karnawati, D., 2005. Bencana Alam Gerakan Massa Tanah di Indonesia dan Upaya Penanggulangannya 
[Natural Hazard due to Mass Movementin Indonesia and the Countermeasures]. Yogyakarta: Department of Geology Engineering, Universitas Gadjah Mada.

Ministry of Agriculture, 1980. Letter of Decree No. 837/KPTS/UM/11/1980 on Criteria and Determination of Protected and Production Forest. Ministry of Agriculture.
Ministry of Public Works, 2007. Law of Ministry of Public Works No. 22/PRT/M/2007 on Guidelines of Spatial Management in Lanslide Prone Area s.l.: Ministry of Public Works. 
[this page intentionally left blank] 